\title{
Paleostress analysis as a key to margin extension: The Penghu Islands, South China Sea
}

\author{
Jacques Angelier a , Françoise Bergerat ${ }^{a}$, Hao Tsu Chu ${ }^{\text {, }}$, \\ Wen Shing Juang ${ }^{\mathrm{b}}$ and Chia Yu Lu ${ }^{\mathrm{c}}$ \\ ${ }^{a}$ Tectonique quantitative, URA 1315 CNRS, T25-26 El, Université P.\& M. Curie, 75252 Paris Cedex 05 (France) \\ ${ }^{b}$ Central Geological Survey, M.O.E.A., P.O. Box 968, Taipei (Taiwan, China) \\ c Department of Geology, National Taiwan University, 245 Choushan Road, Taipei (Taiwan, China)
}

(Received April 28, 1989; revised version accepted October 6, 1989)

\begin{abstract}
Angelier, J., Bergerat, F., Chu, H.T., Juang, W.S. and Lu, C.Y., 1990. Paleostress analysis as a key to margin extension: The Penghu Islands, South China Sea. In: J. Angelier (Editor), Geodynamic Evolution of the Eastern Eurasian Margin. Tectonophysics, 183: 161-176.
\end{abstract}

The Penghu Islands belong to the Eurasian passive margin, west of the collision zone of Taiwan. From south to north, the South China Sea basins become narrower and disappear in the Taiwan Strait area. The presence of the Penghu Islands allow description of the tectonic evolution of the margin through the reconstruction of tectonic paleostress orientation based on analysis of fault slip data collected in the field. Brittle structures have been studied on four islands in Neogene basalt flows with thin interbedded sediments.

Sets of minor striated faults, tension gashes, dikes and joints enabled us to reconstruct the orientation of late Cenozoic stresses. Two main extensional tectonic events were thus identified: a N-S extension dominated during the Middle-Late Miocene (especially in the northern Penghu Islands), and a more recent NW-SE extension prevailed during the Late Miocene (especially in the southernmost island). The latter extension induced complicated patterns of perpendicular normal fault systems and strike-slip conjugate and transfer fault systems, through permutations between principal stress axes $\left(\sigma_{1} / \sigma_{2}\right.$ and $\sigma_{2} / \sigma_{3}$ modes). The ages of these tectonic events are ascertained by the existence of syndepositional normal faults, dike injections and superposed brittle structures. A third, less important compressional tectonic event, is correlated with the Plio-Quaternary collision in adjacent Taiwan (ENE-WSW compression).

The comparison between the results of marine studies in the South China Sea basins and our paleostress reconstruction in the Penghu Islands suggests that repeated changes between N-S and NW-SE directions of extension occurred in the past. The counterclockwise change from N-S to NW-SE recorded in the Penghu Islands took place between about 12 and $8 \mathrm{Ma}$ ago, indicating that significant extensional phenomena along the South China margin may postdate the seafloor spreading activity in the central ridge.

\section{Introduction}

The Penghu Islands, previously called the Pescadores, are located in the southern Taiwan Strait, between Taiwan and the mainland (Fig. 1). The Penghu archipelago includes sixty-four islands and islets on both sides of the Tropic of Cancer, and it constitutes part of the continental shelf, in water depths shallower than $100 \mathrm{~m}$. Chimei, the southernmost island, is close to the ENE-WSW trending slope of the South China
Sea passive margin; the distance between Chimei and the top and the base of the steep continental slope averages 50 and $100 \mathrm{~km}$ respectively (Fig. 1).

Due to this particular location close to the upper part of the passive margin, it is possible to study some characteristics of the Neogene extensional tectonics related to major rifting processes in the South China Sea by means of field observation and data collection in the Penghu Islands. Note that the Penghu Islands are close to, but outside the Taiwan orogen (Ho, 1979); as a result, 


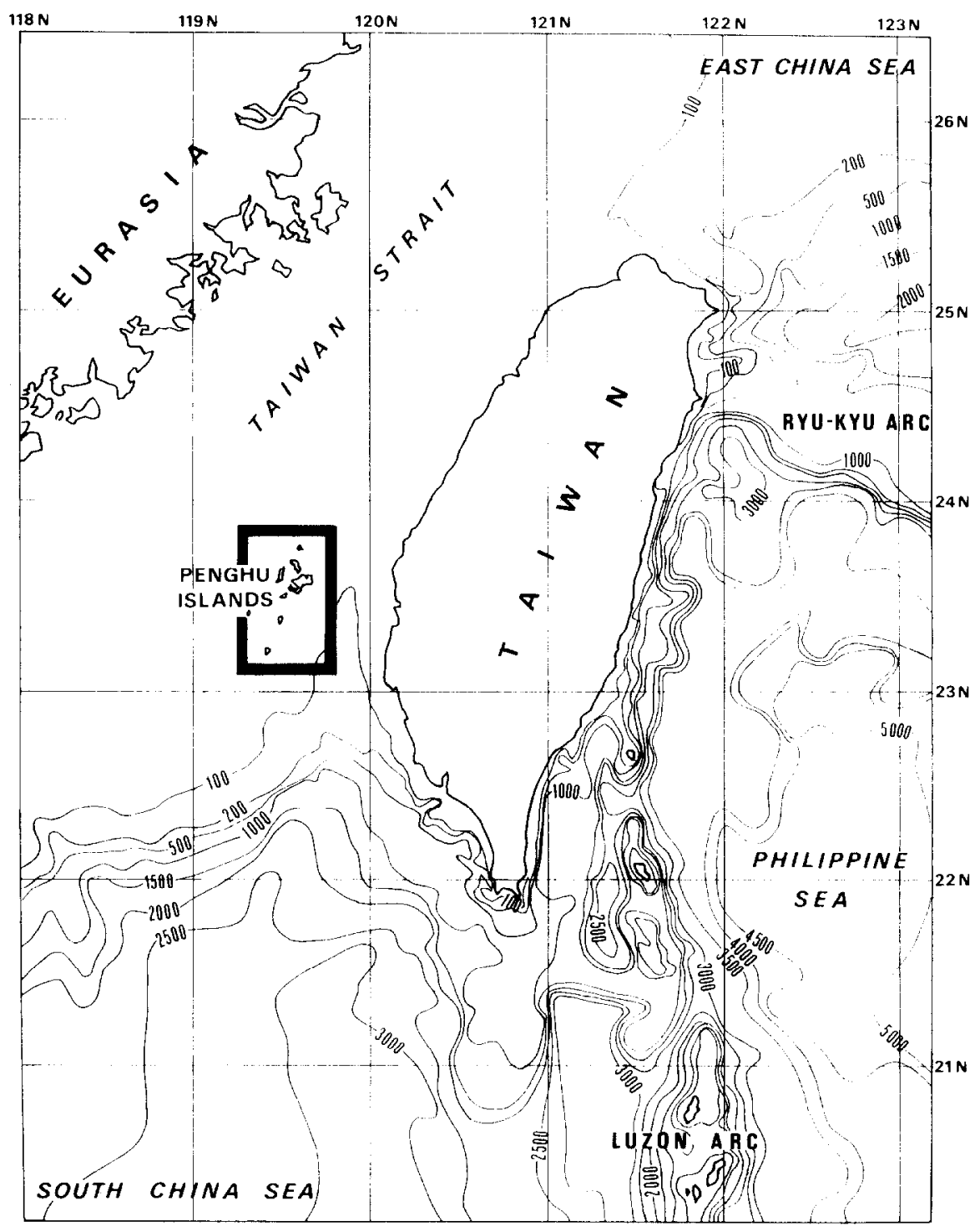

Fig. 1. Location of Penghu Islands and main bathymetric features in the Taiwan Strait area. The box defines the area mapped in Fig. 2. Depths in meters (vertical spacing $500 \mathrm{~m}$, with 100 and $200 \mathrm{~m}$ isobaths added).

no major Plio-Quaternary compressional deformation complicates the previous extensional tectonic pattern.

The tectonic analyses discussed in this paper have been made on the Peng $\mathrm{Hu}$, Pai Sha and $\mathrm{Hsi}$ Yü islands of the main Penghu group, as well as on Chimei island located $45 \mathrm{~km}$ farther to the south (Fig. 2). We shall first briefly describe the geology of the Penghu Islands, then reconstruct their tectonic evolution, and finally discuss the implications of this reconstruction for the evolution of the South China Sea.

\section{The geology of the Penghu Islands}

With the single exception of the westernmost island, which is composed of pre-Neogene porphyrite, the Penghu Islands are mainly composed of late Cenozoic basalt lavas and in small part of interbedded sedimentary rocks (Fig. 2). 


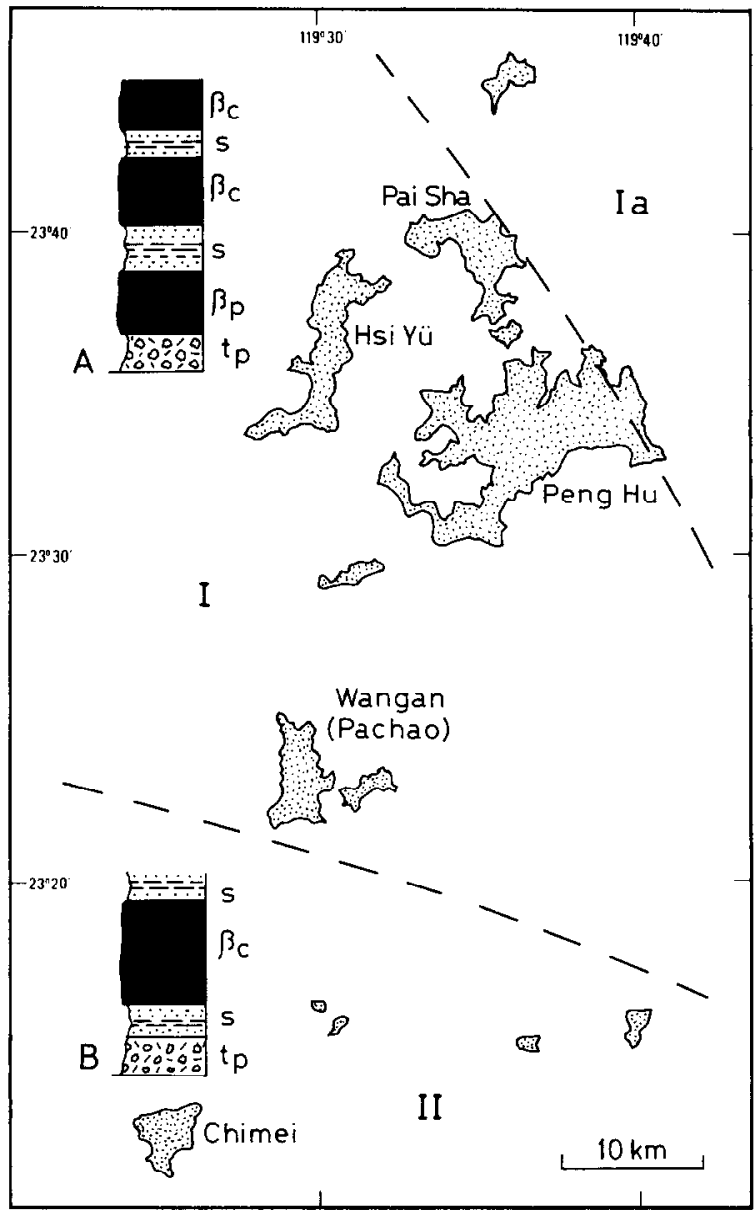

Fig. 2. Islands of the Penghu archipelago mentioned in the text. Areas I, Ia and II represent differences in the nature of the basalt ( $I=$ alkali basalt and tholeiite; Ia = same, with abundant ultramafic nodules; II = alkali basalt; after Juang, 1988). A and B are schematic lithological columns for areas, I $/ \mathrm{Ia}$ and II respectively ( $\beta_{c}=$ columnar basalt: $\beta_{p}=$ platy basalt; $s=$ sediments; $t_{p}=$ pyroclastic tuffs).

Recent Quaternary sediments are present but play a minor role, and will not be discussed hereafter because they simply unconformably overlie the tectonic structures that we have observed.

\section{The Penghu Formation}

The volcanic and sedimentary rocks which form most of the Penghu Islands and all the outcrops that we have studied are known collectively as the "Penghu Formation", and have been described by Yen (1987) and Juang (1988) in the entire archipelago.
Columnar and platy basalt flows dominate and include alkali basalts and tholeiites (Chen, 1973; Juan et al., 1981). Juang (1988) suggests that the alkali basalts are derived from metasomatized, relatively deep mantle, while the tholeiites originated from unmetasomatized mantle lherzolite at a relatively shallow level. He distinguishes three main domains in the Penghu archipelago (Fig. 2): (1) in the main northern islands and in central Wangan (Pachao) island, alkali basalts and tholeiites alternate, (2) to the northeast, within a NW-SE trending zone, the alkali basalts contain numerous ultramafic nodules and (3), to the south, on Chimei and the surrounding islands, alkali basalts clearly dominate.

The volcanic activity that built the basalt flow pile in the Penghu Islands included more than three major phases, each of which produced several lava flows; these basalt flows probably came from several volcanic centers or fissures, and not from a single point (Juang, 1988). Interbedded sediments of the Penghu Formation (Fig. 2) consists of shallow-marine Neogene sandstones and sandy clays (Chou, 1973; Yen, 1987). Basalt effusions have occurred below and above sea level in various locations and time periods and during various stages of uplift-subsidence in the islands.

\section{Age of faulted terranes}

To establish the tectonic history of the Penghu Islands, a crucial point is the age of the basalt flows and interbedded sediments of the Penghu Formation. Despite difficulties in establishing correlations between scattered islands and islets, and although much more radiometric data are needed to reliably reconstruct the magmatic history of the area, a general picture emerges from the limited information presently available.

First, some microfossil assemblages have been identified on Chimei and on another island of the southern Penghu archipelago, and they indicate a Late Miocene age ( - 7-9 Ma); to the north, macro- and microfossils were found but did not allow accurate dating of the sedimentary outcrops in the Penghu Formation (Juang, 1988).

Second, seven radiometric ages have been obtained in the basaltic flows and pyroclastic tuff 
layers of the Penghu Islands. We summarize these results here, as they have been discussed in detail by Juang (1988). Four ages may be related to the major alkali-tholeiite basalt flows of the northern group of islands and Wangan (Pachao) island, 12.7, 13.3, 13.5 and 16.2 Ma. Including error bars, these four determinations provide ages between 12 and $17 \mathrm{Ma}$. Three other radiometric ages have been obtained on the southern islands, near Chimei, in the pyroclastic tuff layers (11.2 and 13.2 $\mathrm{Ma}$ ) and in the upper basalt flow (8.2 Ma). Including error bars, they range between 8 and 14 Ma. These preliminary results suggest that the main basalt flows of the Penghu Islands are Middle-Late Miocene in age and significantly younger in the south (about $8 \mathrm{Ma}$ ) than in the north (about $12 \mathrm{Ma}$ and older); the youngest ages, near Chimei, are consistent with micropaleontological data.

From our standpoint, these results provide a preliminary but fairly consistent chronological basis: we conclude that the faulted columnar basalt flow and underlying sediments that we have studied in Chimei belong to the Late Miocene ( $\sim 7-9 \mathrm{Ma})$. In contrast, the faulted basalts, pyroclastites and sediments in most of our sites in the northern islands (Hsi Yü, Pai Sha and Penghu) are probably older, belonging to the Middle Miocene ( 12-17 Ma).

\section{Structure of the Penghu area}

The geological structure of the Penghu Islands area is known from field mapping, drilling and marine geological and geophysical studies. The Penghu Formation has remained flat lying, and except for rare fault scarps mappable tectonic features are almost absent (Juang, 1988, and geological map in progress). A well was drilled in 1966 in Pai Sha by the Chinese Petroleum Corporation (Huang, 1967). From top to base, the rock units identified belong to the multiple basalt and sediment layers of the Penghu Formation $(0-300$ $\mathrm{m})$, to Miocene alternations of shales and sandstones dated by microfossil analysis $(300-500 \mathrm{~m})$ and to the pre-Neogene basement, including porphyrite $(500-900 \mathrm{~m})$.

Using this drill hole information and gravity data, and comparison with subsurface data from the western coastal plain of Taiwan, Huang (1967) and Pan (1967) published general W-E cross sections showing the deepening of the top of the pre-Neogene substratum, from $-500 \mathrm{~m}$ (Pai Sha, in the Penghu Islands) to $-1700 \mathrm{~m}$ (on land, near the western coast of Taiwan). Pan (1967) pointed out that the pre-Neogene substratum also deepens west and southwest of the Penghu high. The data provided by geophysical gravity and magnetic surveys in the Penghu area are consistent with these interpretations (Pan, 1967; Bosum et al. 1970; Chang and $\mathrm{Hu}, 1981$ ).

Based primarily on seismic reflection surveys, the structure of submarine Tertiary basins in the Taiwan Strait area has been recognized; Sun (1982) published cross sections and structural maps showing the tectonic framework of the Paleogene and late Cenozoic basins. The Neogene structure is mainly characterized by WSW-ENE trending normal-faulted basins with very thick Neogene sediment infill along the South China Sea margin southwest of Taiwan (the Tainan Basin), about 50 $\mathrm{km}$ south-southeast of the Penghu Islands; normal faults with similar WSW-ENE trends bound the Penghu Basin with a Neogene sediment infill of about $1300 \mathrm{~m}$ in thickness approximately $50 \mathrm{~km}$ north-northwest of the Penghu Islands. Thus, the Penghu Islands represent the top of a horst 100 $\mathrm{km}$ wide that trends WSW-ENE parallel to the passive margin of the South China Sea.

To the east, in Taiwan, the structure and sedimentation of this system of WSW-ENE trending late Cenozoic basins and horsts is strongly affected by the lithospheric flexure process and compressional tectonism related to the Taiwan orogen (not discussed in the present paper). Most of the normal faulting that controlled the major horst and graben structures and the development of basins parallel to the South China Sea margin (Sun, 1982) clearly predates most of this compressional evolution (Ho, 1979). The relative importance of compressional structures rapidly decreases from east to west in the strait in offshore Taiwan. As a consequence, no major influence of younger collision processes complicates the antecedent tectonic pattern in the Penghu Islands (contrary to onshore Taiwan), thus explaining our preference for studying the Neogene extensional 
tectonics related to the evolution of the South China Sea Basin in this area (Angelier et al., 1988, 1989).

\section{Paleostress evolution of the Penghu Islands}

In the Penghu Islands (Fig. 2), we have carried out an analysis of minor faults and related fracture patterns in nine main localities on the Peng $\mathrm{Hu}$, Pai Sha and Hsi Yü islands of the northern group, and at four main localities of Chimei island to the south (Figs. 3 and 4).

\section{Methods of paleostress reconstruction}

The methods of fault-slip analysis used by us in the Penghu Islands have been described and discussed in detail in previous papers (Angelier, 1984, 1989) and extensively applied in Taiwan (Angelier et al., 1986; Barrier and Angelier, 1986). These methods consist of determining the best fitting reduced paleostress tensor for a given fault-slip data set, thus identifying the attitudes of the three principal stress axes (maximum compressional stress $\sigma_{1}$, intermediate stress $\sigma_{2}$ and minimum stress $\left.\sigma_{3}\right)$ and the ratio $\phi=\left(\sigma_{2}-\sigma_{3}\right) /\left(\sigma_{1}-\sigma_{3}\right)$ between principal stress magnitudes.

Despite the small amount of total deformation in the Penghu Islands, numerous minor striated faults were found in many outcrops, so the faultslip analysis methods mentioned above could be successfully applied (Figs. $3 \mathrm{~A}$ and $4 \mathrm{~A}$, and Table 1). Significant amounts of fault-slip data have been collected, most of it in the sediments, at the basalt-sediment interface and in the pyroclastic tuffs. Because total deformation remains small, these sets of minor faults are scattered over large areas. As a result, many sites are practically monophase and reveal relatively simple conjugate patterns of neo-formed faults; in this case, simple methods are also valid (Huang and Angelier, 1989). Other sites, however, display more complicated fault patterns including oblique and inherited fault slips, so numerical reconstructions of reduced paleostress tensors (Angelier, 1984) were necessary.

Other fractures have commonly been observed in the Penghu Islands, most of them being tension joints, tension cracks and dikes (Figs. 3B and 4B). Although it is possible to distinguish cooling and

TABLE 1

Results of paleostress determinations using faults-slip data sets in the Penghu Islands. Diagrams shown in Figs. 3A and 4A. Methods: Angelier $(1984,1989)$. All angles in degrees. Ratio $\phi$ defined in text. Reduced tensors determined using new direct inversion method: "Average angle" refers to the average angles of the largest possible values of actual slip-computed shear. Estimated quality decreases from $A$ to $E$.

\begin{tabular}{|c|c|c|c|c|c|c|c|c|c|c|}
\hline \multirow[t]{2}{*}{$\bar{N}$. } & \multicolumn{2}{|l|}{$\sigma_{1}$ axis } & \multicolumn{2}{|l|}{$\sigma_{2}$ axis } & \multicolumn{2}{|l|}{$\sigma_{3}$ axis } & \multirow{2}{*}{$\begin{array}{l}\text { Ratio } \\
\phi\end{array}$} & \multirow{2}{*}{$\begin{array}{l}\text { Number } \\
\text { of faults }\end{array}$} & \multirow{2}{*}{$\begin{array}{l}\text { Average } \\
\text { angle }\end{array}$} & \multirow{2}{*}{$\begin{array}{l}\text { Estimated } \\
\text { quality }\end{array}$} \\
\hline & Trend & $\overline{\text { Plunge }}$ & Trend & $\overline{\text { Plunge }}$ & Trend & $\overline{\text { Plunge }}$ & & & & \\
\hline \multicolumn{11}{|c|}{ Fig. $3 A$} \\
\hline $1 \mathrm{a}$ & 144 & 74 & 333 & 16 & 242 & 2 & 0.5 & 6 & 4 & E \\
\hline $1 \mathrm{~b}$ & 298 & 20 & 99 & 69 & 206 & 6 & 0.5 & 14 & 17 & D \\
\hline 3 & 79 & 88 & 287 & 2 & 196 & 1 & 0.3 & 28 & 12 & B \\
\hline 5 & 122 & 6 & 31 & 5 & 260 & 83 & 0.8 & 43 & 23 & $\mathrm{C}$ \\
\hline 6 & 296 & 84 & 83 & 5 & 173 & 3 & 0.3 & 32 & 14 & A \\
\hline $7 \mathrm{~b}$ & 141 & 78 & 254 & 5 & 345 & 11 & 0.2 & 15 & 12 & $\mathrm{C}$ \\
\hline $10 \mathrm{a}$ & 109 & 64 & 296 & 26 & 205 & 3 & 0.4 & 8 & 15 & D \\
\hline $10 \mathrm{~b}$ & 110 & 81 & 348 & 5 & 257 & 8 & 0.2 & 5 & 8 & $\mathrm{E}$ \\
\hline \multicolumn{11}{|c|}{ Fig. $4 A$} \\
\hline $1 \mathrm{a}$ & 56 & 80 & 324 & 0 & 234 & 10 & 0.3 & 20 & 16 & $\mathrm{C}$ \\
\hline $2 a$ & 206 & 77 & 36 & 13 & 305 & 2 & 0.4 & 32 & 12 & A \\
\hline $2 b$ & 226 & 13 & 321 & 20 & 106 & 66 & 0.2 & 14 & 14 & $\mathrm{C}$ \\
\hline $4 a$ & 194 & 88 & 50 & 1 & 320 & 1 & 0.3 & 14 & 15 & $\mathrm{C}$ \\
\hline $4 \mathrm{~b}$ & 218 & 86 & 321 & 1 & 51 & 4 & 0.5 & 32 & 12 & B \\
\hline
\end{tabular}


tectonic joints in basalt flows, we restricted our study of joints to the sedimentary layers in which there is no ambiguity. Besides, tectonic joints are less abundant in columnar basalts than in competent sedimentary beds, because pre-existing cooling joints release energy and tend to prevent the development of tectonic fractures. We point out that in most cases tension features such as joints, gashes and dikes were found to be consistent with fault-slip data sets (i.e., they are perpendicular to the $\sigma_{3}$ axis of the paleostress tensor, which was reconstructed independently). Shear and hybrid joints (Hancock, 1985) are less abundant than tensional features but they are also present in the Penghu Islands; they were found to be mechanically consistent with striated faults observed at the same sites.

We conclude that although our tectonic analysis is primarily based on paleostress reconstructions using fault-slip data (Figs. $3 \mathrm{~A}$ and $4 \mathrm{~A}$ ), the orientations of the other fractures, and especially of the joints, provide a reliable complementary record of paleostress orientations (Figs. 3B and 4B, and Table 1).

\section{Directions of extension across the China shelf on the Penghu Platform}

Figures 3 and 4 illustrate the data collected and the paleostress determinations made in the Hsi Yü-Pai Sha-Peng Hu island group and on Chimei island respectively. In each figure, fault slips (A) and joints (B) have been distinguished for clarity. Paleostress axes $\sigma_{1}, \sigma_{2}$ and $\sigma_{3}$ reconstructed after fault-slip data analysis and tensor determinations are shown in Figs. 3A and 4A (see also Table 1). Dike orientations, local folds (in the case of Chimei) and tension gashes are added in Figs. 3B and $4 \mathrm{~B}$. The corresponding directions of extension (and/or compression) are summarized in both cases; determinations made using fault-slip data sets have greater accuracy and greater value than determinations made using data from other tectonic features.

Most sites on the studied islands show extensional brittle structures. In the northern group of islands (Fig. 3), two sites on Hsi Yü and Peng $\mathrm{Hu}$ show consistent $\mathrm{N}-\mathrm{S}$ trending extension with numerous striated normal faults (Fig. 3A, see 3,6 and $7 b$ ) and vertical tension joints (Fig. 3B, see 4 and $6 \mathrm{~b}$ ). Most normal faults effectively strike $\mathrm{E}-\mathrm{W}$ and belong to dip-slip conjugate systems; tension joints also strike E-W. In addition, fractures without any slickenside lineation or observable offset have the same strike and dip as the normal faults and should be interpreted as normal conjugate shear joints (Fig. 3B, see 7). Several dikes are vertical and trend approximately $\mathrm{E}-\mathrm{W}$ (6a in Fig. 3B).

Although this $\mathrm{N}-\mathrm{S}$ extension clearly predominates in the northern islands, other extensional tectonic features are also present (Fig. 3), such as NW-SE trending vertical tension joints and hybrid joints (Fig. 3B, see 1 and 3) and some normal faults, indicating a NE-SW trending extension (Fig. 3A, see 1a).

To the south on Chimei island, minor normal faults and tension joints also dominate (Fig. 4). The striated faults generally belong to normal dip-slip conjugate systems, and strike either NE$\mathrm{SE}$ or NW-SE, i.e. at right angles (Fig. 4A, compare $2 a-4 a$ with $1 a-4 b$ ). Accordingly, the reconstructed directions of extension are either NW-SE or NE-SW, depending on the site (Fig. 4A). Vertical dikes that trend approximately NESW have been observed ( $2 \mathrm{a}$ and $3 \mathrm{a}$ in Fig. 4B), as well as large sets of subvertical tension joints that strike approximately NE-SW and NW-SE (Fig.

Fig. 3. Fracture data and paleostress reconstruction in the northern group of Penghu Islands (Hsi Yü, Pai Sha and Peng Hu). Diagrams are Schmidt's stereographic projections of lower hemisphere. (A) Analysis of fault-slip data sets. (B) Analysis of other fractures, especially joints and dikes. Diagrams are numbered according to site reference numbers in map. Faults and fracture planes shown as thin lines; slickenside lineations shown as small dots on fault planes with small, thin outward directed arrows (normal slip). inward directed arrows (reverse slip) or double arrows (dextral or sinistral slip). Computed paleostress axes $\sigma_{1}, \sigma_{2}$ and $\sigma_{3}$ shown as $5-$, 4- and 3-pointed stars respectively (see Table 1 for details). Large black arrows indicate computed directions of extension and compression (as referred to in Table 1) in (A), and inferred directions of extension and compression in (B). Smaller diagrams show syndepositional fault (A) or dikes (B). 







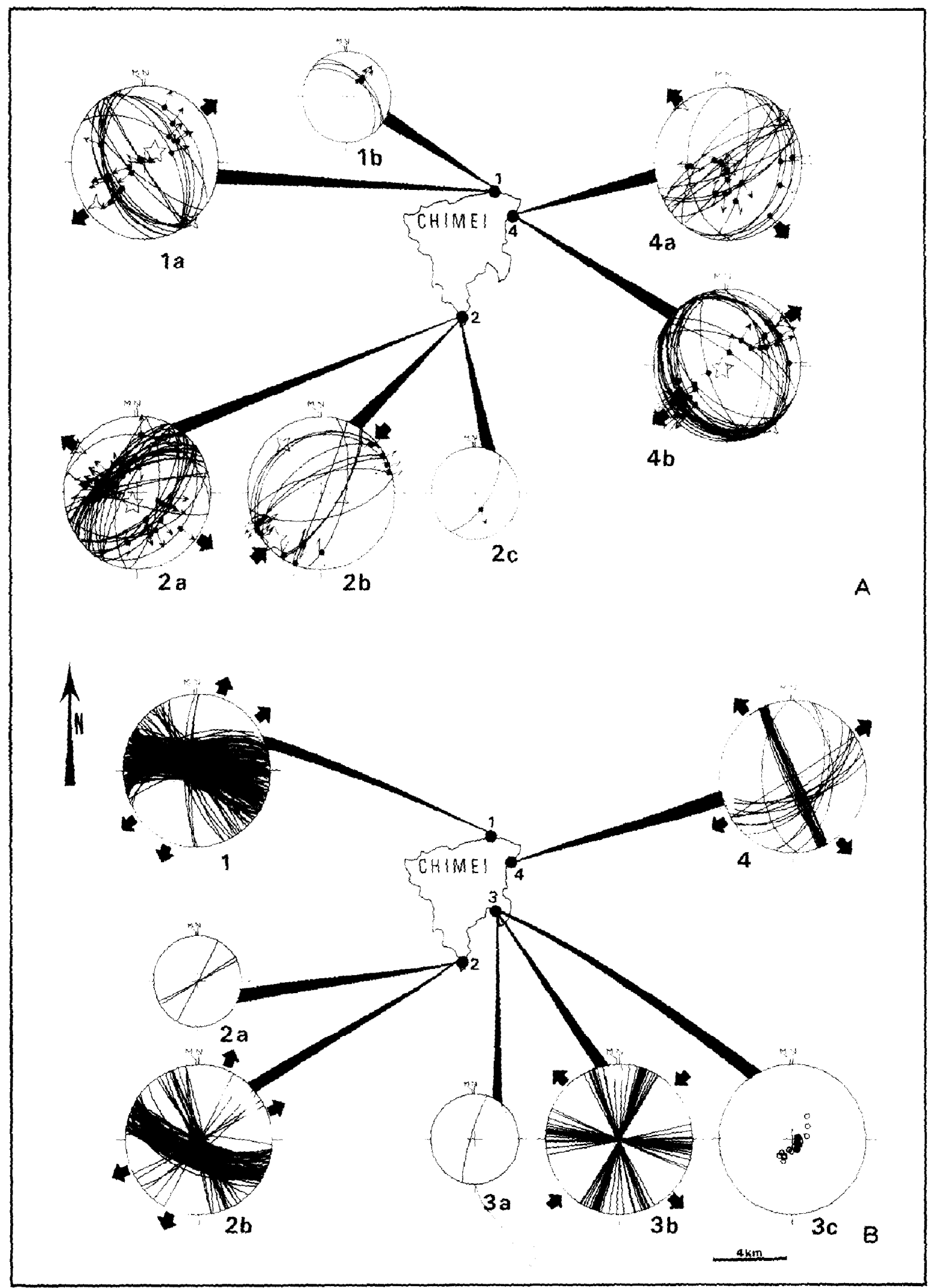

Fig. 4. Fracture data and paleostress reconstruction on Chimei island. Explanation as for Fig. 3, except for diagrams $3 \mathrm{~b}$ and $3 \mathrm{c}$ in (B). $(3 \mathrm{~b}=$ faults without observable dips and striae; $3 \mathrm{c}=$ poles to bedding shown with circles. 
$4 B$, see $2 b$ and 4). These patterns are in agreement with the paleostress orientations reconstructed before.

However, numerous vertical tension joints with strikes close to E-W are also present and complicate the fracture pattern on Chimei (Fig. 4B, see 1). As in the northern islands, normal hybrid and shear joints are found; some are consistent with $\mathrm{N}-\mathrm{S}$ extension while others correspond to the main NW-SE/NE-SW extensions (Fig. 4B, see 1 and 4).

\section{Strike-slip faults: apparent and actual compression}

Although they play a minor role, small compressional structures have been found at three sites on Hsi Yü and Pai Sha islands in the north. Minor reverse faults with rare strike-slip faults ( $1 b$ and 5 in Fig. 3A) and tension and hybrid vertical joints are consistent with a compressional axis $\sigma_{1}$ that trends WNW-ESE. One site with few strikeslip faults on Penghu island suggests the same direction of $\sigma_{1}$ (not shown in Fig. 3).

The most spectacular structures, however, have been found on Chimei island, where strike-slip faults mechanisms indicate $\sigma_{1}$ and $\sigma_{3}$ axes that respectively trend NE-SW and NW-SE (2b in Fig. 4A). These mechanisms are compatible with strike-slip fractures and the NW-SE trending axis of gentle hectometre-sized folds observed at another site (Fig. 4B, 3b and 3c). Contrary to the northern examples mentioned before, we consider that most of the strike-slip faults on Chimei do not reflect actual compressional tectonics, because reverse faulting is absent and because the direction of extension related to strike-slip mechanisms trends parallel to the $\sigma_{3}$ axis indicated by the numerous normal-slip mechanisms already discussed. We conclude that the relationship between the paleostresses responsible for these two types of mechanisms on Chimei is principally a change affecting principal axes $\sigma_{1}$ and $\sigma_{2}$, the direction of extension remaining constant. Alternatively, strike-slip faulting and gentle folding on Chimei island may be attributed to actual compression. Strike-slip faults and structural inversion have been described in the Yellow Sea basins of the East China Sea and on the margin of the South
China Sea, and interpreted in terms of MiddleLate Miocene compressional tectonics (Letouzey et al., 1987-1988). Our main reasons for relating the structures that we have observed on Chimei to NW-SE extension rather than to actual compression are the presence of the common trend of $\sigma_{3}$ axes (Fig. 4) and the synchronism suggested by the variety of relative age relationships.

Likewise, the coexistence of two conjugate normal fault systems with strictly perpendicular trends, as pointed out before, indicates that a permutation between principal axes $\sigma_{2}$ and $\sigma_{3}$ has probably occurred during the extension, the $\sigma_{1}$ axis remaining constant (compare 1a, 2a, 4a and $4 \mathrm{~b}$ in Fig. 4A). Such paleostress changes have already been described in other regional rift settings (Angelier and Bergerat, 1983).

Summarizing, the extensional fault structures on Chimei island display a high level of apparent complexity because two types of permutation between principal stress axes (mode $b, \sigma_{1} / \sigma_{2}$ and mode $a, \sigma_{2} / \sigma_{3}$ ) have occurred within the framework of dominating extension along NW-SE trends, respectively resulting in complicated changes from normal dip-slip to strike-slip faulting and from longitudinal to transverse dip-slip normal faulting. The absence of definite consistent chronological relationships and the spatial correlation between these patterns, as well as the exact perpendicularity of geometrical and mechanical axes, also supports our interpretation of stress "oscillations" during a single major extensional event (instead of distinct tectonic events).

Finally, a more detailed analysis of strike-slip fault systems on Chimei suggests that there are two types of wrench faulting related to extension. The NW-SE trending folds ( $3 \mathrm{c}$ in Fig. 4B) developed along a major NNW-SSE subvertical fault which is probably a transfer fault inducing particular local deformation modes. In contrast, other dextral and sinistral strike-slip faults simply correspond to the $\sigma_{1} / \sigma_{2}$ permutation already discussed (mode $b$ ). Such a contrast between transfer faults (more-or-less parallel to extension, and generally inconsistent in terms of regional stress) and conjugate strike-slip faults (oblique at large angles to, and mechanically consistent with regional extension) has already been pointed out in the Basin 
and Range province (Michel-Noël and Angelier, 1989).

\section{Ages of tectonic events}

The ages of brittle tectonism in the Penghu Islands may be established in two ways. First, direct or indirect observation on polyphase structures allows identification of a relative tectonic chronology. As an example of direct observation, short NW-SE vertical tension joints commonly abut against long $\mathrm{E}-\mathrm{W}$ ones, indicating that the NE-SW extension is younger than the $\mathrm{N}-\mathrm{S}$ extension. As an example of indirect observation, the existence of some normal faults striking $\mathrm{E}-\mathrm{W}$ that bear oblique slickenside lineations with NE-SW trends (normal-dextral) also suggests that the first $\mathrm{N}-\mathrm{S}$ extension developed conjugate systems of normal shear joints (or normal dip-slip faults whose striae have been erased by later movements) and that the second NE-SW extension reactivated these fractures as oblique-slip faults. All these relative chronology indicators concur to demonstrate that the $\mathrm{N}-\mathrm{S}$ extension (Fig. 6A) is older than the NW-SE/NE-SW extension (Fig. 6B).

As pointed out before, no clear picture of relative chronology emerges from individual relationships among (i) normal faulting consistent with NW-SE extension (ii), strike-slip faulting consistent with the same extension, and (iii) transverse normal faulting related to NE-SW extension, because these mechanisms are clearly related through stress permutations and were probably approximately contemporaneous (see previous subsection).

The WNW-ESE compression recorded in the Hsi Yü, Pai Sha and Peng Hu Islands (Fig. 6c) is clearly younger than the $\mathrm{N}-\mathrm{S}$ extension according to tectonic criteria (superpositions of slickenside lineations and fracture intersections).

The second means of recognizing the chronology of tectonics events involves age determinations in the rock formations affected, and identification of syntectonic volcanic and sedimentary structures. At one site on Peng $\mathrm{Hu}$ island ( $7 \mathrm{a}$ in Fig. 3A), syndepositional minor normal faults were observed (Fig. 5A), showing that the sediments
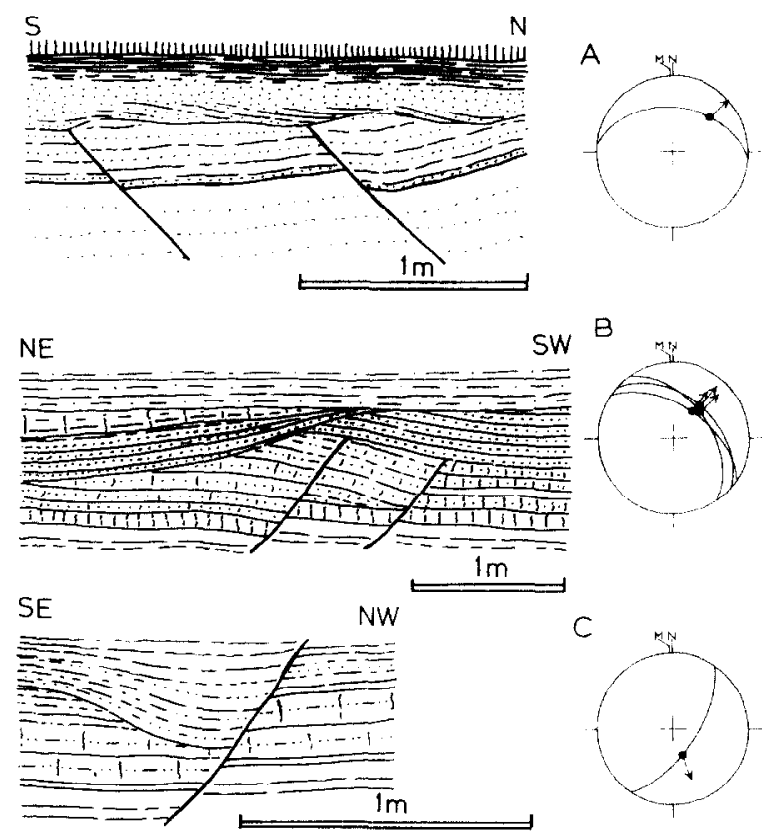

Fig. 5. Syndepositional normal faults observed in the sediments of the Penghu Formation, and their orientations (Schmidt's projection, lower hemisphere, normal striae as dots with arrows). Location in Fig. 3A (site 7a for A) and Fig. 4A (sites $1 \mathrm{~b}$ for $\mathrm{B}$ and $2 \mathrm{c}$ for $\mathrm{C}$ ).

(now between two major lava flows) were formed while extension was active. $\mathrm{E}-\mathrm{W}$ trending vertical dikes are present at another site on the same island (6a in Fig. 3B), indicating that basalt injection cannot predate the development of $\mathrm{E}-\mathrm{W}$ fractures and suggesting that it occurred under the $\mathrm{N}-\mathrm{S}$ extensional regime.

Likewise, syndepositional minor normal faults were observed at two sites on Chimei island (1b and $2 \mathrm{c}$ in Fig. 4A); they trend NW-SE and NE$\mathrm{SW}$ (Figs. 5B and $\mathrm{C}$ respectively). Their presence shows that the sediments (now beneath the main columnar basalt flow) were formed while the major NW-SE and the auxiliary NE-SW trending extensions were active, thus confirming the synchronism of these orthogonal extensions. Observation of basaltic dikes ( $2 \mathrm{a}$ and $3 \mathrm{a}$ in Fig. 4B) shows that injection occurred either in vertical NE-SW tension fractures (the most common case) or in NNE-SSW and ENE-WSW vertical strike-slip faults, suggesting again that most tectonic features on Chimei are consistent with a single major extensional event. 

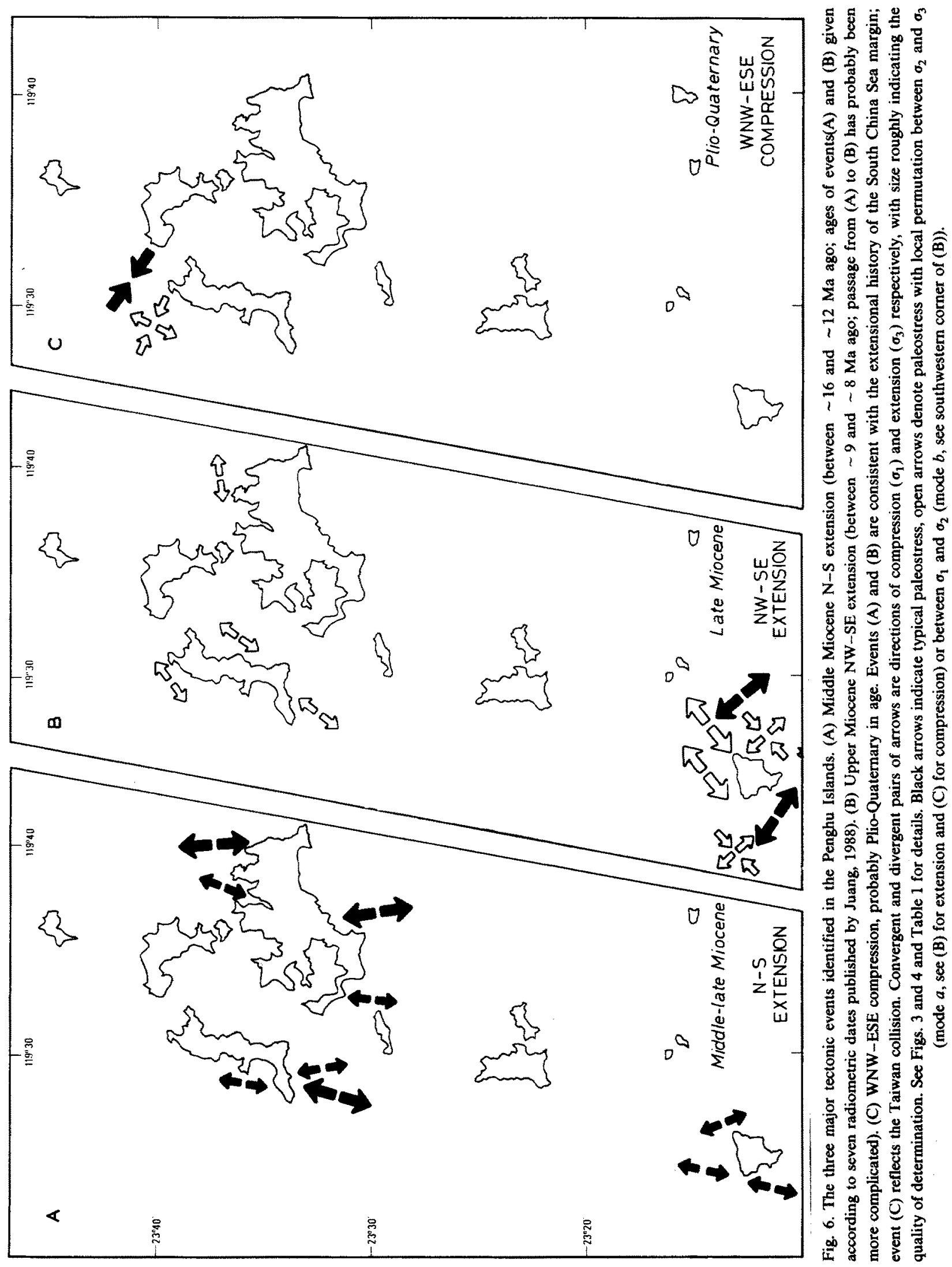


\section{Tectonic evolution}

We conclude that during the Middle Miocene, approximately $12-16$ Ma ago, $\mathrm{N}-\mathrm{S}$ extension clearly prevailcd in the Penghu area, as demonstrated in the northern islands. In contrast, during the Late Miocene, approximately 8-9 $\mathrm{Ma}$ ago, NW-SE extension was clearly predominant, as shown on Chimei (Figs. 6A and B). This interpretation is consistent with our relative tectonic chronology of faulting events as well as with available radiometric ages and micropaleontological dating in syntectonic rock units. The results summarized in Fig. 3 and Table 1 indicate that the average trends of $\sigma_{3}$ are close to $\mathrm{N} 10^{\circ} \mathrm{E}$ for the $\mathrm{N}-\mathrm{S}$ extension, and to $\mathrm{N} 140^{\circ} \mathrm{E}$ for the NW-SE extension.

The presence of rare but significant features that correspond to $\mathrm{N}-\mathrm{S}$ extension on Chimei (especially the dense tension joint patterns along the northern coast) suggests either that the change from $\mathrm{N}-\mathrm{S}$ to NW-SE extension occurred during the Late Miocene, when the basalts and sediments were forming in Chimei, or, much more likely, that N-S and NW-SE extensions may have been alternating, at least during a limited period of the Late Miocene. In the absence of a continuous volcanic and sedimentary record, however, a more complex succession of N-S and NW-SE extensions cannot be detected.

The relative intensity and the remarkable complexity of fault tectonics related to the NW-SE extension on Chimei, compared with its poor development in the northern islands, should be explained by the particular location of Chimei, the closest island to the continental slope of the South China Sea (Fig. 1). In addition, taking into account the synchronism between extensional tectonic activity and the formation of basalts and sediments that outcrop in northern and southern Penghu Islands, we consider that the extensional tectonism probably controlled the volcanic activity and the sedimentation, with a migration from north (Hsi Yü, Pai Sha and Peng $\mathrm{Hu}$ ) to south (Chimei) during the Middle-Late Miocene. Note, however, that this conclusion strongly depends on the validity of available radiometric dates in the northern Penghu Islands (Juang, 1988).
One may attribute the NW-SE extension (Fig. $6 \mathrm{~B})$ to the effects of plate bending related to the collision between the Luzon Arc and the South China margin. According to this hypothesis, the downwarping of the continental margin west of the Taiwan collision zone would have induced the development of normal faults parallel to the flexure axis. We rejected this possibility in the case of the Late Miocene extension on Chimei, because (1) the trend of $\sigma_{3}$ axes (NW-SE) is not perpendicular to the trend of the lithospheric flexure (NNE-SSW) west of Taiwan, and (2) the convergent boundary was much farther east of the Penghu area during the Late Miocene than it is now (Fig. 7).

Finally, the WNW-ESE compression detected in the northern islands (Fig. 6C) is post-depositional, post-volcanic and younger than at least the $\mathrm{N}-\mathrm{S}$ extension. We relate it to the main compressional events of the major Plio-Quaternary collision in Taiwan, whose directions of compression are fairly similar (Angelier et al., 1986).

\section{Tectonic evolution of Penghu Islands and the South China Sea}

The late Cenozoic evolution of the South China Sea includes rifting and seafloor spreading processes. To summarize this evolution (Fig. 7), we refer to the results of the offshore studies carried out during the last 10 years in two key areas: the basins of the South China shelf and continental margin between Hainan and Taiwan, and the oceanic floor on both sides of the axial spreading ridge west of Luzon. This system of continental shelf and margin, abyssal plains and oceanic ridge, with WSW-ENE trends on average, has a half-width of about $1000 \mathrm{~km}$ (from Hong Kong on the mainland coast to the Scarborough seamounts on the axial ridge off Luzon). To the east, close to $120^{\circ} \mathrm{E}$, this South China Sea structural pattern is cut by an E-dipping convergent boundary that trends $\mathrm{N}-\mathrm{S}$ : the collision zone of Taiwan to the north (in front of the South China margin) and the Manila Trench subduction zone to the south (in front of the abyssal plains and ridge). 

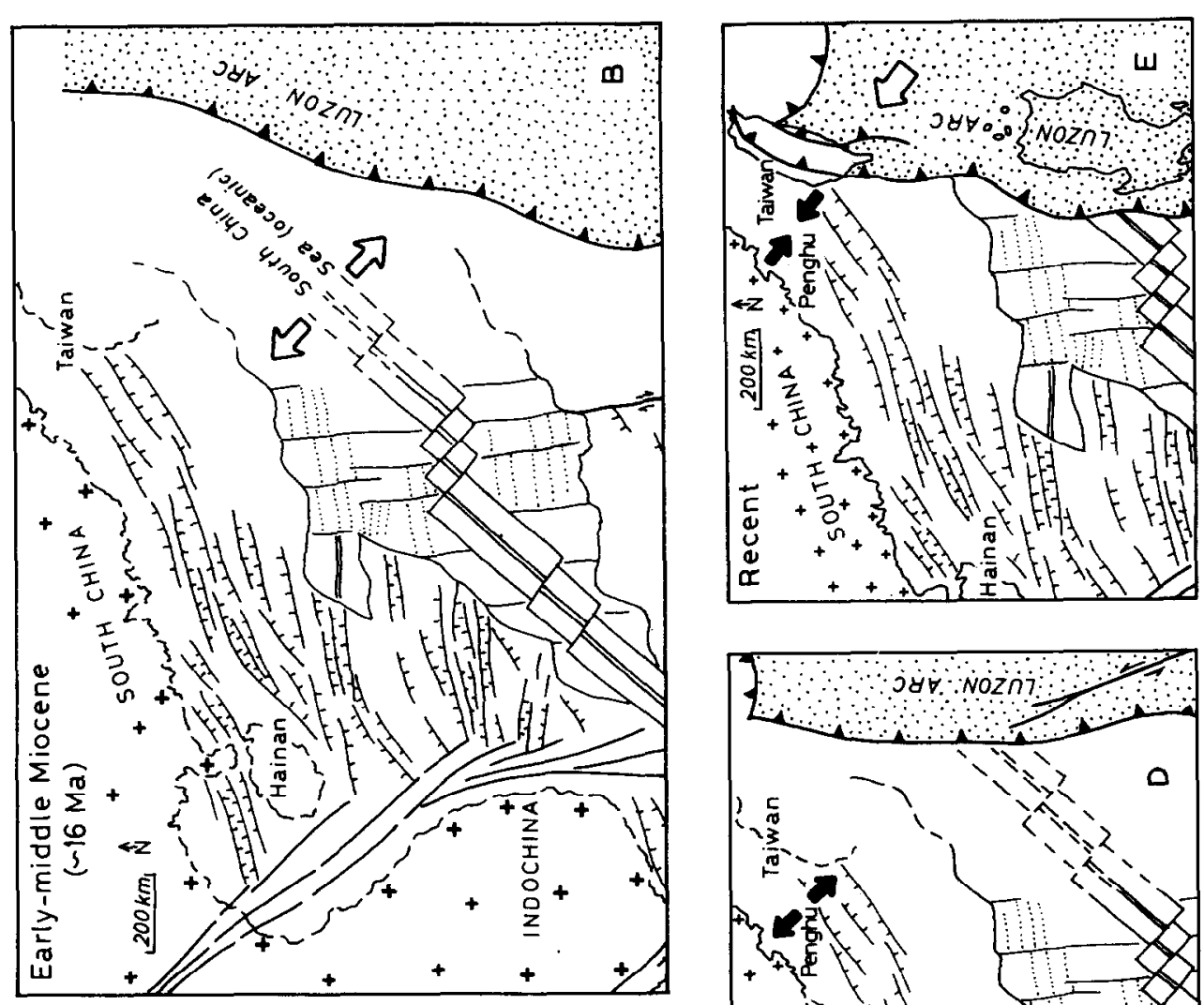

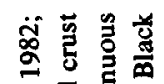

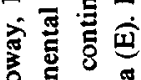
응 롤 용 \% 려

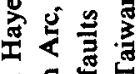
콩 园 옹 吾 㧜

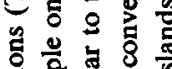

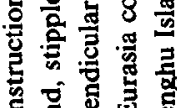

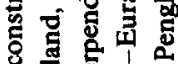
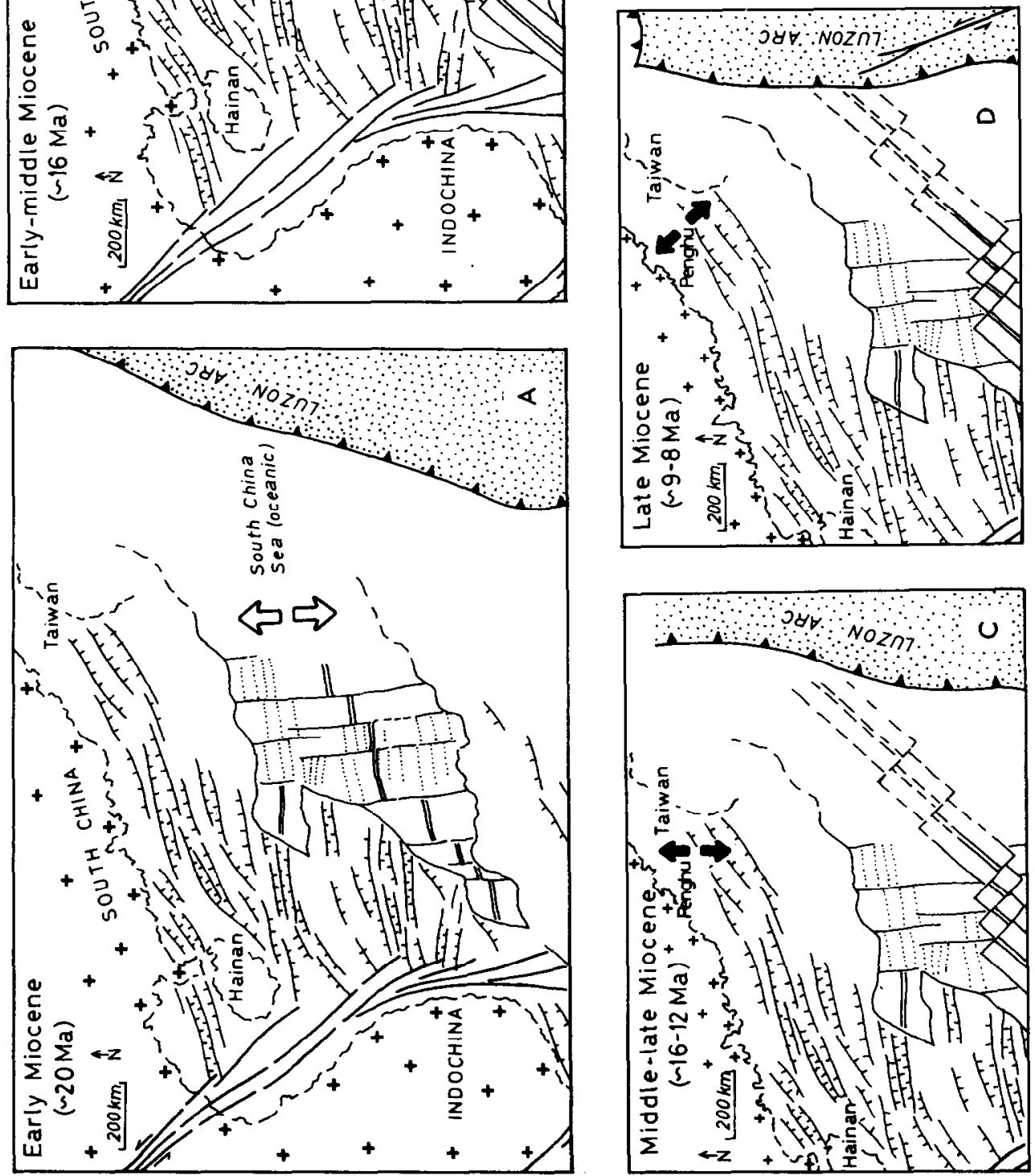

ह E

के है क्ष

可急造

도에웡

호 흥

영 도로용

专 总

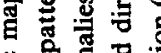

卷岇焉 हृ 施安造

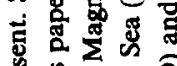

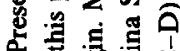
9 为导

岁 昰 코원

즐

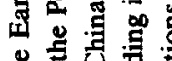
동

응 के 흥

은

.

ฐ 동 용

अ

봉 需

过芯疍

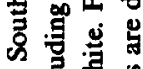

들

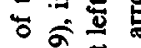

홍 矛 명

ํำ ส่

ㄷㅎㅇ

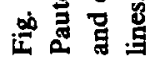




\section{Seafloor spreading in the South China Sea}

The evolution of the oceanic basins of the South China Sea was analysed by Taylor and Hayes (1980 and 1983) and Holloway (1982), based principally on bathymetry, magnetic anomaly patterns, heat-flow data and seismic reflection profiles. As a result, Taylor and Hayes (1983) identified a major period of seafloor spreading as midOligocene-Early Miocene in age (between 32 and $17 \mathrm{Ma}$ ), with $\mathrm{E}-\mathrm{W}$ trending magnetic lineations and half-spreading rates from 2.2 to $3 \mathrm{~cm} / \mathrm{yr}$. However, a recent more detailed survey of the axial zone of the South China Sea led Pautot et al. $(1986,1989)$ to distinguish structural grains that trend $\mathrm{N} 50^{\circ} \mathrm{E}$ near the axis of the basin, in contrast with the $\mathrm{N} 80^{\circ} \mathrm{E}$ structural fabric that prevails at a distance of about $100 \mathrm{~km}$ or more away from the basin axis. These authors conclude that seafloor spreading has occurred along a NW-SE direction, perpendicular to normal fault scarps and magnetic anomalies and parallel to transform fault segments, during the most recent phase of seafloor spreading that began about $20 \mathrm{Ma}$ ago and finished about $16 \mathrm{Ma}$ ago (Fig. 7).

The direction of earlier seafloor spreading has been disputed (see discussion in Pautot et al., 1986; Briais et al., 1988). Based on the E-W orientation of magnetic anomalies identified in the main abyssal plains north and south of the axial zone, most authors consider that from about 32 to $20 \mathrm{Ma}$, seafloor spreading occurred along a N-S direction (Taylor and Hayes, 1980, 1983; Holloway 1982). Pautot et al. (1989) point out that recent studies of magnetic anomalies in the eastern South China Sea support this interpretation. This implies that a significant counterclockwise rotation of the direction of spreading and corresponding extension from $\mathrm{N}-\mathrm{S}$ to $\mathrm{NW}-\mathrm{SE}$ occurred about $20 \mathrm{Ma}$ ago (Fig. 7).

\section{Evolution of the South China margin}

Regional offshore studies based primarily on seismic reflection profiles and subsidence data from wells has provided accurate information on the structural evolution of the South China margin ( $\mathrm{Ru}$ and Pigott, 1986) within the general frame- work of the southeastern Eurasian margin (Letouzey et al., 1988). Several basins, including the major Pearl River Mouth Basin, have been studied along the continental margin that trends WSW-ENE over a distance of more than $1400 \mathrm{~km}$ from Hainan to Taiwan, between the mainland and the deep South China Sea (Sun, 1982; Pigott and Ru, 1988; Yu, 1988; Yuan et al., 1988).

Subsidence data indicate that major rifting events occurred along this margin during the Late Cretaceous-Early Paleogene about $65 \mathrm{Ma}$ ago, the Late Eocene-Early Oligocene about $35 \mathrm{Ma}$ ago, and the late Middle Miocene about $13 \mathrm{Ma}$ ago ( $\mathrm{Ru}$ and Pigott, 1986). Concerning the most recent evolution, Ru and Pigott (1986) pointed out that a small but significant increase in subsidence rate took place during the last $4 \mathrm{Ma}$ (Plio-Pleistocene). These authors mentioned the correlation between these subsidence events and the main periods of basaltic volcanic activity, especially for the events which occurred between 13-11 and $4 \mathrm{Ma}$ ago. They finally distinguished heating-rifting events in contrast with longer periods of seafloor spreading, especially the last Late Oligocene-Early Miocene spreading of the eastern South China Sea that took place from 32 to $16 \mathrm{Ma}$ ago according to Taylor and Hayes (1983) and Pautot et al. (1989).

Interpretation of tectonic data in the Penghu Islands

Because no formation older than the MiddleLate Miocene outcrops on the Penghu Islands (with the exception of the westernmost island), our results in terms of paleostress orientation are not relevant as far as the pre-Neogene evolution of the South China margin is concerned. It is interesting, however, to observe that according to $\mathrm{Ru}$ and Pigott's reconstruction (1986) for the Paleogene, and to the recent observations in the central spreading ridge area for the Neogene (Pautot et al., 1986, 1989), repeated changes between $\mathrm{N}-\mathrm{S}$ and NW-SE directions of extension took place on the scale of the entire South China Sea Basin. The counterclockwise change from the $\mathrm{N}-\mathrm{S}$ to the NW-SE direction of extension recorded in the fault tectonic evolution of the Penghu Platform (this paper) is very similar, although the scale of 
the phenomenon and the methodology used to recognize it are quite different.

It is certainly hazardous to extrapolate the late Cenozoic paleostress history reconstructed on the Penghu Islands to the scale of the entire South China margin (Fig. 7). Emergent outcrops suitable for fault-slip data collection are rare in this context, so extensive mapping of paleostress trajectories cannot be carried out. However, there is an excellent agreement between the directions of extension reconstructed by independent means in the deep basins of the South China Sea and on the Penghu Islands. This agreement suggests that our local results actually reflect large-scale mechanisms.

According to the age determinations obtained in the Penghu Formation (Juang, 1988) and to the inferred ages of magnetic anomalies in the oceanic basins (Pautot et al., 1989), and even taking into account reasonable error bars, it seems impossible to correlate the similar counterclockwise changes of the direction of extension that have been identified in the Penghu Islands (Late Miocene, $\sim 8-12$ $\mathrm{Ma}$ ago) and strongly suspected $100 \mathrm{~km}$ away from the ridge axis west of Luzon (Early Miocene, - $20 \mathrm{Ma}$ ago). We conclude that such changes may have been frequent during the Cenozoic evolution of the South China Sea. In more detail, note that repeated changes have effectively been suspected in the Penghu Islands based on reasoning using tectonic chronology.

We finally observe that significant extensional tectonic activity (with definite $\mathrm{N}-\mathrm{S}$ and NW-SE trends of minimum stress $\sigma_{3}$, Figs. $6 \mathrm{~A}$ and $\mathrm{B}$ ) occurred very late in the history of the South China continental margin after seafloor spreading ceased along the central oceanic ridge. Note, incidently, that because in our study the tectonic mechanisms are reconstructed based on fault-slip data and not simply inferred from fault orientations, the presence of inherited basement faults related to the pre-Neogene history of the Taiwan Strait (Sun, 1982), possibly propagating upward during Neogene reactivation, cannot vitiate the paleostress determinations and hence the reconstructed directions of extension.

The last tectonic event recorded by minor faulting on the Penghu Platform (Fig. 6C) reflects the
WNW-ESE compression of the Taiwan collision which developed during the Plio-Quaternary a short distance east of the Penghu Islands (now less than $100 \mathrm{~km}$ ). Although the high amounts of younger compressional deformation make paleostress reconstruction of Miocene tectonism more difficult in the mountain ranges of Taiwan than on the Penghu Platform, the few reliable determinations that could be made indicate (after backtilting) very similar directions of extension, ranging from N-S to NW-SE (Angelier et al., 1986).

In the case of the South China Sea margin, complete regional mapping of paleostress trajectories based on accurate fault-slip data collection cannot be undertaken in the way that it can for emergent continental platforms. Local determinations, however, provide accurate constraints in geodynamic reconstructions, such as the recent contrasting interpretations of the kinematic evolution of the South China Sea and surrounding basins based on syntheses of marine studies and reconstitution of large-scale Indo-Asian collision tectonics (Briais et al., 1988, 1989; Taylor and Rangin, 1988).

\section{Acknowledgements}

Field studies were supported by the Central Geological Survey of Taiwan and the French C.N.R.S. (A.S.P. "Blocs et Collisions", contribution DBT 113) within the framework of the SinoFrench cooperation program between the National Science Council of Taiwan (Prof. C.S. Ho) and the French Institute in Taipei (Mr. P. Mallet). Constructive comments were made by J. Letouzey and T.P. Yen.

\section{References}

Angelier, J., 1984. Tectonic analysis of fault slip data sets. J. Geophys. Res., 89: 5835-5848.

Angelier, J., 1989. From orientations to magnitudes in paleostress determinations using fault slip data. J. Struct. Geol., 11: 37-50.

Angelier, J. and Bergerat, F., 1983. Systèmes de contrainte et extension intracontinentale. Bull. Cent. Rech. Explor. Prod. Elf-Aquitaine, 7: 137-147. 
Angelier, J., Barrier, E. and Chu, H.T., 1986. Plate collision and paleostress trajectories in a fold-thrust belt: the Foothills of Taiwan. Tectonophysics, 125: 161-178.

Angelier, J., Bergerat, F., Chu, H.T., Juang, W.S. and Lu, C.Y., 1988. Paleostress analysis as a key to margin extension: the Penghu Islands, South China Sea. In: Int. Symp. Geodynamic Evolution of the Eastern Eurasian Margin (Paris) p. 23 (Abstr.).

Angelier, J., Bergerat, F., Chu, H.T., Juang, W.S. and Lu, C.Y., 1989. Extensional tectonics and opening of the South China Sea Basin: field data from Penghu Islands (Taiwan Strait). EUG 5 (Strasbourg). Terra Abstr., 1: 210.

Barrier, E. and Angelier, J., 1986. Active collision in eastern Taiwan: the Coastal Range. Tectonophysics, 128: 39-72.

Bosum, W., Burton, G.D., Hsieh, S.H., Kind, E.G., Schreiber, A. and Tang, C.-H., 1970. Aeromagnetic survey of offshore Taiwan. CCOP Tech. Bull., pp. 295-328 and ECAFE, 3: $1-34$.

Briais, A., Tapponnier, P., Patriat, P., Lacassin, R., Leloup, H., Shaerer, U., Zhong, D. and Wang, K., 1988. The Tertiary opening of the South China Sea and other extensional basins of the Sunda shelf: a consequence of the collision between India and Asia. In: Int. Symp. Geodynamic Evolution of the Eastern Eurasian Margin (Paris), p. 33 (Abstr.).

Briais, A., Tapponnier, P., Patriat, P. and Wang, K., 1989. The Tertiary opening of the South China Sea: a consequence of the collision between India and Asia. EUG 5 (Strasbourg). Terra Abstr., 1: 210.

Chang, S.S.L. and Hu, C.C., 1981. Gravity and magnetic anomalies of Taiwan and their tectonic implication. Mem Geol. Soc. China, 4: 121-142.

Chen, J.C., 1973. Geochemistry of basalts from Penghu Islands. Proc. Geol. Soc. China, 16: 23-26.

Chou, J.T., 1973. Sedimentology and paleogeography of the upper Cenozoic system of western Taiwan. Proc. Geol. Soc. China, 16: 111-143.

Hancock, P.L., 1985. Brittle microtectonics: principles and practice. J. Struct. Geol., 7: 437-457.

Ho, C.S., 1979. Geologic and tectonic framework of Taiwan. Mem. Geol. Soc. China, 3: 57-72.

Holloway, N.H., 1982. North Palawan Block, Philippines-its relations to Asian mainland and role in evolution of South China Sea. Am. Assoc. Pet. Geol. Bull., 66: 1355-1383.

Huang, Q. and Angelier, J., 1989. Inversion of field data in fault tectonics to obtain the regional stress. II. Using conjugate fault sets within heterogeneous families for computing stress axes. Geophys. J., 96: 139-149.

Huang, T.Y., 1967. Foraminiferal study of the Tungliang well TL-1 of the Penghu Islands. Pet. Geol. Taiwan, 5: 131-149.

Juan, V.C., Chen, C.-H. and Lo, H.J., 1981. Tectonic implication of Neogene volcanism on the continental shelf of western Taiwan. Mem. Geol. Soc. China, 4: 195-205.

Juang, W.S., 1988. Geochronology and chemical variations of late Cenozoic volcanic rocks in Taiwan. Thesis, Natl. Taiwan Univ., Taipei, 231 pp. (Unpubl.).
Letouzey, J., Sage, L. and Muller, C., 1987-1988. Geological and structural map of Eastern Asia: Introductory notes. Inst. Fr. Pét. and Am. Assoc. Pet. Geol., 72 pp.

Letouzey, J., Sage, L. and Muller, C., 1988. Geological and structural map of Eastern Asia. In: Int. Symp. Geodynamic Evolution of the Eastern Eurasian Margin (Paris) p. 76 (Abstr.).

Michel-Noël, G. and Angelier, J., 1989. Formation des basins en extension: comparaison de deux ensembles dans le "Basin and Range", U.S.A. Bull. Soc. Géol. Fr.. 8, 5: 523-532.

Pan, Y.S., 1967. The regional gravity of the Penghu Islands, Taiwan, China. Pet. Geol Taiwan, 5: 117-129.

Pautot, G., Rangin, C., Briais, A., Tapponnier, P., Beuzart, P., Lericolais, G., Mathieu, X., Wu, J., Han, S., Li, H., Lu, Y. and Zhao, J., 1986. Spreading direction in the Central South China Sea. Nature, 321 (6066): 150-154.

Pautot, G., Ranging, C., Briais, A., Wu, J., Han, S., Li, H., Lu, Y. and Zhao, J., 1989. The axial ridge of the South China Sea: a Seabeam and geophysical survey. Oceanol. Acta, in press.

Pigott, J.D. and Ru, K., 1988. Pulsed basin evolution on the northern margin of the South China Sea. In: Int. Symp. Geodynamic Evolution of the Eastern Eurasian Margin (Paris) p. 88 (Abstr.)

Ru, K. and Pigott, J.D., 1986. Episodic rifting and subsidence in the South China Sea. Am. Assoc. Pet. Geol. Bull., 70: $1136-1155$.

Sun, S.C., 1982. The Tertiary basins of offshore Taiwan. In: Proc. ASCOPE Conf. and Exhib., 2nd, pp. 125-135.

Taylor, B. and Hayes, D.E., 1980. The tectonic evolution of the South China Basin. In: D.E. Hayes (Editor), The Tectonic and Geologic Evolution of Southeast Asian Seas and Islands. Am. Geophys. Union Geophys. Monogr., 23: 89-104.

Taylor, B. and Hayes, D.E., 1983. Origin and history of the South China Sea Basin. In: D.E. Hayes (Editor), Am. Geophys. Union Geophys. Monogr., 27: 23-56.

Taylor, B. and Rangin, C., 1988. Tertiary right-lateral pull-apart basins along the Asian-PAcific margin: constraints on the propagating extrusion model of Indo-Asian tectonics.In: Int. Symp. Geodynamic Evolution of the Eastern Eurasian Margin (Paris), p. 100 (Abstr.).

Yen, T.P., 1987. Geology of the Penghu Islands. Taiwan. Bull. Geophys., Natl. Cent. Univ., Chungli (Taiwan), 27-28: $1-43$.

Yu, H.S., 1988. Tectonic evolution of the Pearl River Mouth Basin off the South China Coast. Acta Oceanogr. Taiwan., 20: 79-94.

Yuan, J., Yan, K.M., Chi, W.R., Hu, C.C. and Chou, T.F., 1988. Episodic faulting on the Tertiary continental margin of western Taiwan. In: Int. Symp. Geodynamic Evolution of the Eastern Eurasian margin (Paris), p. 110 (Abstr.). 